Social pitfalls for river restoration: How public participation uncovers problems with public acceptance

Heldt, Sonja; Budryte, Paulina; Ingensiep, Hans-Werner;
Teichgräber, Burkhard; Schneider, Ute; Denecke, Martin

The following text is provided by DuEPublico, the central repository of the University DuisburgEssen.

This version of the e-publication released on DuEPublico may differ from a potential published print or online version.

DOI: http://dx.doi.org/10.1007/s12665-016-5787-y

URN: urn:nbn:de:hbz:464-20161215-130806-9

Link: http://duepublico.uni-duisburg-essen.de/servlets/DocumentServlet?id=42954

License:

(c)

This work may be used under a Creative Commons Namensnennung 4.0 International license. 


\title{
Social pitfalls for river restoration: How public participation uncovers problems with public acceptance
}

\author{
Sonja Heldt ${ }^{1}$ - Paulina Budryte ${ }^{1} \cdot$ Hans Werner Ingensiep ${ }^{2} \cdot$ Burkhard Teichgräber $^{3}$. \\ Ute Schneider $^{4} \cdot$ Martin Denecke ${ }^{1}$
}

Received: 31 December 2015/Accepted: 26 May 2016/Published online: 27 June 2016

(c) The Author(s) 2016. This article is published with open access at Springerlink.com

\begin{abstract}
As in several other infrastructure sectorshighly popular German examples are the protests concerning "Stuttgart 21" or Munich airport-the people's "new voice" is severely inhibiting the enforcement progress of common legislation in the water management sector, in particular the European Water Framework Directive (2000; EU-WFD). With the launch of the EUWFD, the European Union is forcing serious changes in watersheds to reach a "good ecological status". However, although affirmatively described by experts, not all of these changes are appreciated by local communities. According to Connif (2014), $75 \%$ of river restoration projects did not reach their minimal goals due to the lack of active stakeholder involvement. To prevent this, a comprehensive consideration of social aspects is essential for a sustainable implementation success of river restoration projects in the German water management sector. In this paper, local
\end{abstract}

This article is part of a Topical Collection in Environmental Earth Sciences on "Water in Germany", guest edited by Daniel Karthe, Peter Chifflard, Bernd Cyffka, Lucas Menzel, Heribert Nacken, Uta Raeder, Mario Sommerhäuser and Markus Weiler.

Sonja Heldt

sonja.heldt@uni-due.de

$\triangle$ Paulina Budryte

paulina.budryte@stud.uni-due.de

1 Department of Water and Waste Management, University of Duisburg-Essen, Universitätsstr. 15, 45141 Essen, Germany

2 Faculty of Philosophy, University of Duisburg-Essen, Universitätsstr. 12D, 45117 Essen, Germany

3 Emschergenossenschaft/Lippeverband, Kronprinzenstraße 24, 45128 Essen, Germany

4 Historical Institute, University of Duisburg-Essen, Universitätsstr. 12, 45141 Essen, Germany stakeholders' individual acceptance and the overall public acceptance of the project to ecologically improve the Emscher River's mouth in the context of the Emscher Conversion ("Emscherumbau") and its relation to certain steps of action in the project (including public participation measures) will be discussed as a case study. To our knowledge, no other research has been conducted so far combining the advantages of qualitative stakeholder interviews and a comprehensive media analysis to get an individual insight into the attitude of different stakeholder groups and to consistently identify snapshots of the public attitude during the course of the project. At first sight the project has high potential for conflicts because of drastic alterations of the current environment, intense construction works and soil transport activities, a relatively dense settlement in close proximity as well as a community that is experienced in asserting their rights. But although public participation was basically limited to information and formal consultation, the local attitude towards the ecological improvement of the Emscher River's mouth is overall positive.

Keywords Emscher Conversion - EU-WFD - River basin management $\cdot$ River restoration - Acceptance Public participation - Water infrastructure

\section{Introduction}

The German public increasingly demands information and participation in the decision-making process concerning the implementation of big infrastructure projects. "Without acceptance, no success" (Hitschfeld and Lachmann 2013) accurately describes the overall situation. The new train station in Stuttgart, the expansion of Munich Airport or 
various projects connected to the transformation of the German energy system are revealing examples of the increasing protest attitude (BDI 2011; VDI 2014). Fiftyeight percentage of the general public is convinced that it is "difficult" or "very difficult" to implement big infrastructure projects in Germany and only $40 \%$ think that local public acceptance is a relevant criteria in the planning process (IDA 2011).

Integrating public participation at an early stage in the planning process is, according to the literary canon, the most effective way to involve the public and find an overall accepted solution (Bertelsmann Stiftung 2013; BMVI 2014; Hennecke and Kronenberg 2014; VDI 2014). Although more and more national and international laws and agreements support early forms of public participation, actual implementations are often limited to formal information and consultation.

The water infrastructure sector is currently facing a transition process. On EU level, the Water Framework Directive (EU-WFD) (2000/60/EG) legally requires fundamental alterations in the existing system. Besides, demographic, climatic and industrial changes prove to be severe challenges and locally the pressure to act is high.

In general, due to the legal validity of the EU-WFD, all river restoration projects nowadays are supported by a comprehensive management concept on river basin scale. But overall, the implementation of the EU-WFD in Germany is lagging behind (UBA 2012). Although the EUWFD fiercely acknowledges the importance of the public and its involvement (Preamble No. 14 EU-WFD), the authorities' missing ability to generate acceptance was identified as one of the main issues causing the current delay in German implementations (UBA 2012). Moreover, $75 \%$ of the implemented river restoration projects did not reach their minimal goals because of insufficient stakeholder involvement (Connif 2014).

Article 14 of the EU-WFD addresses "public information and consultation". It requires formal public participation and supports active public participation during the development process of River Basin Management Plans (RBMPs). While formal participation is described in detail in the directive, it provides no binding guideline on how to implement the recommended active part. In Germany, the EU-WFD is enacted by the "Wasserhaushaltsgesetz" (WHG) on national level and by the specific water laws for every state on federal level ("Landeswassergesetze"). On project level, formal public participation ensures that every affected party can participate in the approval procedure, and in most cases, critical issues have to be negotiated in a public hearing. While public participation on river basin level is open for everyone (UBA 2006), on project level, formal public participation is only including immediately affected stakeholders.
There is a big pool of literature that assess either the effectiveness of public participation in the EU-WFD in general (e.g. Collins et al. 2007; Jager et al. 2016; van der Heijden and ten Heuvelhof 2012; Kastens and Newig 2008; Muro 2002; Newig 2005; Newig and Fritsch 2009; Özerol and Newig 2008) or the implementation of (best practice) examples in certain case studies (e.g. Bherer and Breux 2012; de Groot and van der Nat 2011; Hillebrand et al. 2011; Warner et al. 2011). But articles that explicitly link certain steps of action in a river restoration project, where public participation is more or less restricted to information and formal consultation, with public and individual acceptance are missing. In order to fill this gap this paper uses a new mix of methods, combining qualitative stakeholder interviews to get an individual insight into the attitude of different stakeholder groups and a comprehensive media analysis offering snapshots of the public attitude during the course of the project.

The ecological improvement of the Emscher River's mouth is one part of the Emscher Conversion. The Emscher Conversion is currently one of the biggest infrastructure projects in Germany. The entire river system of the Emscher is meant to be ecologically improved-from its source in Holzwickede to its mouth in the Rhine in Dinslaken (Reicher et al. 2011; Skodra 2014; WIKUE 2013). In the Rhenish-Westphalian industrial region, surface water bodies were unable to cope with the anthropogenic pressure that was accompanied by the development of the mining sector during the industrial revolution. In particular, along the Emscher River, frequent flooding and outbreaks of water-borne diseases demanded action. Due to continuous subsidence caused by high mining activities in the area, it was impossible for the local water board (Emschergenossenschaft; EG) to install underground sewers to solve hygienic problems. Thus, the Emscher was put in a straight, concrete bed to serve as a regulated open sewer for the whole area (www.eglv.de). Since the 1980s, mining activities have been declining and within the Emscher Conversion it is finally possible to relocate the sewer system under the ground. In contrast to infrastructure projects of comparable size, the overall project has no notable delays in the implementation, up to now. A special feature of this case study is that the project is additionally part of an accompanying campaign on river basin scale that communicates the Emscher Conversion as one comprehensive measure to the public. Thus, the influence of synergistic effects of both strategies on the individual acceptance of local stakeholders towards the project as well as on the overall public acceptance of these extensive changes will be also analysed.

It is important to keep in mind that this work solely deals with the acceptance of the project and not with its acceptability. In contrast to acceptability, acceptance is 
purely descriptive and not normative (Hermelink 2008; Tschiedel 1989).

\section{Theoretical background}

\section{River restoration}

The recognition of river restoration projects is particularly high as they change the appearance as well as the social, ecological and economic function of a public environment essentially. Due to these multiple interferences, the planning and implementation of river restoration will provoke ambitious issues. Uhlendahl (2009) states that besides conflicts related to values, stakeholder relations and coordination, the main reasons for opposing interests in river basin planning are the structure of the river bed, the area, water quantity and emission into the rivers. These issues can be divided into several subissues, e.g. flood protection, leisure usage, policy and economy.

Besides these ecological, political, technical and economical discourses, rivers and their floodplains also play a highly emotional role in place attachment (Lindemann 2011; Buijs 2009). Lindemann (2011) argues that in this context, the river can represent (1) a "physical place"; (2) a "social and cultural locus" and (3) a "symbol for the total environment". Besides the technical construction, this means that the planning and implementation of river restoration projects have to live up to expectations in multiple sectors, including different interest groups and individuals. Moreover, the interconnection of river basin processes causes interlinkages with other project systems and thus adds another important dimension to the already complex field. Therefore, river restoration has to be seen as "problem-in-context" (de Groot 1998) and can only be assessed from an inter- and transdisciplinary perspective (Farrell et al. 2012) that is embracing the public participation of all affected stakeholders.

\section{Acceptance}

It is highly important to understand that acceptance is not a stable property that can either be present or not. Acceptance is "the result of a dynamic, reciprocal process between a subject and an object in a certain context" (Lucke 1995) and therefore has to be maintained all the time. In order to discuss the acceptability of the project, these reasons would have to be validated according to their moral integrity and values of "non-human nature" (Jax et al. 2013). While acceptability is "an objective property" (Lucke 1995) of a technique that could be "determined in a verification procedure" (Tschiedel 1989), acceptance can be influenced by generating trust and sharing responsibilities in public participation processes.
Besides trust and other variables presented in Fig. 1, participation itself is one important aspect for the building of acceptance.

\section{Public participation}

The role of the citizens in society has been discussed since the beginning of democracy in ancient Greece (Renn et al. 1995). Today, the debate focuses on the arrangement of new governance forms; how to arrange the decision-making process in a smoother way and how to gain acceptance from a wider number of public stakeholders (Erhard et al. 2013; Oosthuizen 2006). The degree of public participation can vary from information campaigns to giving full control to the citizen (Arnstein 1969). Examples of very high citizen empowerment are "consensus conferences" (Nielson et al. 2006; Skorupinski et al. 2007). In this case study public participation is mainly restricted to extended information and consultation.

Public participation has its advantages but entails certain risks (Luyet et al. 2012). Although critiques state doubts concerning the cost- and time-effectiveness of public participation (especially concerning intensive stakeholder involvement), it guarantees a more positive attitude towards a project in comparison with the status quo situation (Albrecht 2013; Beierlie 2002). But, due to the high dynamic of social systems, there is no sample solution schema on how to design public participation. To build and maintain public acceptance, transparency is essential concerning both information about the project as well as on the possibilities to influence the decision-making process (Hildebrand et al. 2012).

In general, functions and objectives of public participation can be defined as information, control, legal protection, integration and conflict resolution (Muro 2002). Newig (2005) distinguishes between objectives related to legitimacy and efficiency. While legitimacy is mainly linked to precautionary conflict resolution, the efficiency of processes in a project is depending on the quality of decisions and the implementation. The right form of public participation can improve the quality of decisions by providing additional information due to local knowledge and opinions. Additionally, it builds trust and causes procedural justice, which is a necessary precondition for a sustainable acceptance of project implementation (DWA 2008; Karlsen et al. 2008; Newig 2005; Pust 2014).

\section{Public participation and acceptance in river restoration projects}

In sum, stakeholder structures are especially complex when it comes to river restoration projects. A clear objective for the project and the stakeholder management process as 
Fig. 1 Possible variables influencing the reciprocal process of personal acceptance. The variables in the blue boxes are directly influencing a person's individual acceptance. The context variables in the white box are influencing a person's perception and needs concerning the variables in all blue boxes. Context variables are also influenced by the overall public attitude

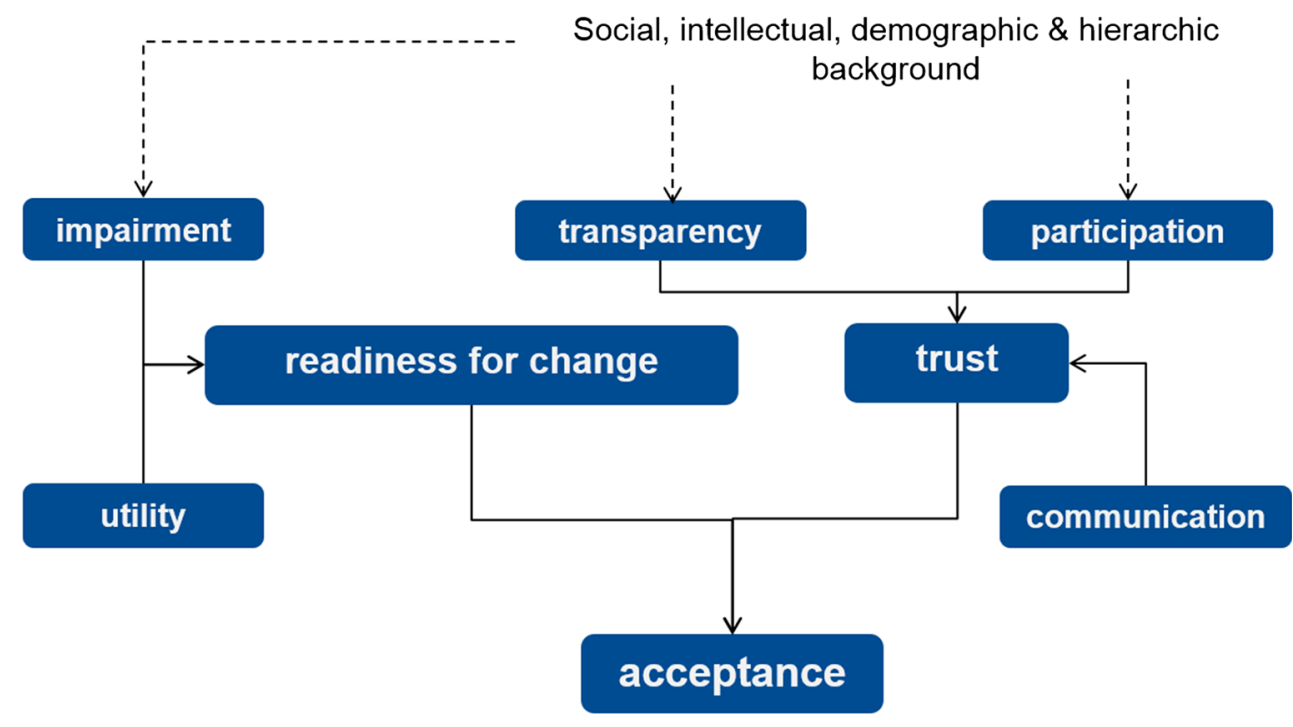

well as a comprehensive stakeholder analysis is essential to enable the determination of an appropriate public participation that positively influences the public acceptance. To build and maintain a trustful relationship - the basis for sustainable acceptance-it is important to offer transparent communication and to share actual responsibilities in order to boost identification with the project.

For technical reasons, it is best to influence important decisions in the early planning phase of a project. But the laws dealing with the implementation of the actual projects only require formal public participation in form of information and consultation during the last approval procedures. Thus, if the responsible project parties simply stick to the legal requirements for public participation, the public stakeholders are being required to notice the announcement for public participation, have to work themselves through folders of documents with technical plans and complex terminology and have to actively formulate their claims in front of experts in a public hearing.

Another factor that has to be incorporated in the design of public participation processes is the stakeholders' motivation to participate. Although in North Rhine-Westphalia on river basin scale, the voluntary framework of the law to enhance early and active public participation is fairly organized, overall it is still facing two main problems in its implementation: the first is that stakeholders' willingness to participate is increasing with the perception of personal disadvantages from the project. In the early planning phase plans are only very vague, and thus, personal disadvantages are not directly recognizable. Therefore, it is difficult to motivate a representative crowd of people to get involved in a time- and resources-consuming public participation process (Roßnagel et al. 2014). Second, an increasing degree of empowerment is correlating with an increasing possibility to take responsibility in the decision-making process for the public. But the higher the degree of empowerment is, the lower is the number of stakeholders that can actually participate in the decisionmaking process (Newig 2005; UBA 2006). This also applies for public participation on river basin scale and thus implies a very complex question: Who has to be involved to guarantee the most possible legitimation for the outcome of the process? A possible answer to this dilemma is the randomized participant selection of "citizen councils" that are not focussing on representativeness but heterogeneity in the decision-making process (Büro der Zukunft 2014).

\section{Methods}

The overall objective of this research is to find out: (1) What is the course of events in the Emscher mouth restoration project and in the public information/participation process? (2) What is the attitude of the local community towards the project and towards the conducted public events? (3) How is the course of events in the project, including public participation at subordinated project scale and the superordinate river basin scale, influencing local stakeholders' individual acceptance as well as the overall public acceptance towards the project?

\section{Case study}

Within the framework of the Emscher Conversion, the ecological improvement of the Emscher mouth in the city of Dinslaken is one of the biggest restoration projects. Today, because of the different water levels of both rivers, the Emscher falls down from a 6-m-tall drop structure into the Rhine. To enable biological connectedness and to provide an important initial point for the spread of sound 
ecological effects, the mouth of the Emscher will be shifted to a location 500-m downstream of the Rhine by elongating the river course by $700 \mathrm{~m}$ using a near-natural, flat-sloped stone ramp. In the project area around the new Emscher mouth, 19-ha natural floodplains, developed by self-dynamic river processes, should offer habitats for a diverse local wildlife.

The city of Dinslaken has 70461 inhabitants (www.din slaken.de). The district of Eppinghoven, the settlement "Am Stapp" and the city border to Voerde are in direct proximity of the construction site of the new Emscher mouth. On top of the Rhine dyke a frequently used bicycle and promenade way attracts many visitors and provides leisure opportunities for local residents. Although there is no intent to build a bridge across the new Emscher mouth, these leisure grounds should be maintained after the implementation of the project. They will still be accessible via a new path following an alternative route. In addition, a permanent information centre for visitors was constructed in the area ("Hof Emschermündung").

Currently, the wastewater treatment plant (WWTP) "Emschermündung" is responsible for purifying the whole river upstream from its location. After its adaption during the Emscher Conversion, the sewage plant will be the final treatment plant for the new underground Emscher sewer. The treated water will then be released into the newly renatured Emscher River.

\section{Process analysis in the project environment}

To provide a basis for the evaluation of public events, a process analysis was conducted, using available planning and approval documents as well as local newspapers. In addition, extensive site visits were incorporated in the data collection process. These visitations of important project sites include: the construction site, "Am Stapp", "Eppinghoven", the dyke promenade, "Hof Emschermündung" and the "Konrad-Adenauer"-street along the soil transportation route. The visits were documented by taking notes and photographs.

In general, information gained in the process should help to understand the previous course of events and can be used to identify all activities of public participation and information that were related to the project or its context.

\section{Media analysis of local newspapers}

The analysis of local newspapers should provide information on the course of project actions and help to identify key players and locations. Furthermore, the media analysis can help to grasp the overall attitude of the population towards the project. It is considered that compared to standardized surveys, the result of a media analysis is not reflecting the actual opinion of a representative sample of local residents, but represents a prior source of information open to the entire public. In particular, in relatively rural areas like Dinslaken, local newspapers are reaching a majority of residents and thus have an important influence on the local formation of opinions. Unlike standardized surveys, a media analysis is also able to identify the relation between certain steps over the course of project actions in retrospective, because newspaper articles can be considered as snapshots of public attitudes. Therefore, adding another perspective by studying the media coverage of the project can significantly contribute to the understanding of the relationships in question.

In the online archives of the region's most influential newspapers Rheinische Post Dinslaken (RP DIN) and the Neue Rhein Zeitung Dinslaken (NRZ DIN) as well as in the media archive of the EG, 521 articles were collected containing the keywords "Emschermündung" or "Dinslaken" and "Emschermündung" or "Emschergenossenschaft". The time frame for articles to be considered relevant was set from May 2007 to November 2015, covering the whole project development period. Selected articles were first sorted by their relevance for the project or the project context (close neighbourhood to the Emscher mouth or explicit reference to the Emscher mouth). Applying this criterion, 295 articles were used for the media analysis (see Table 1).

The content of these articles was further assessed concerning: (1) their attitude towards the project (positive; neutral; negative); (2) the main protagonists; incidents affecting the project/the project area or organizers; and (3) intention, location and participants of events.

\section{Qualitative social survey}

For a detailed assessment of the attitude of the local community towards the project and the conducted public events, qualitative interviews were held with

Table 1 Source of the newspaper articles incorporated in the media analysis

\begin{tabular}{lc}
\hline Newspaper & $\begin{array}{l}\text { Number of articles } \\
\text { in the media analysis }\end{array}$ \\
\hline RP DIN & 135 \\
NRZ DIN & 152 \\
WAZ Duisburg/Moers & 3 \\
WAZ Oberhausen & 1 \\
Ruhr Nachrichten & 1 \\
Lokal Kompass DIN & 1 \\
BILD Ruhrgebiet & 1 \\
NRZ Wesel & 1 \\
Sum & 295 \\
\hline
\end{tabular}


representatives from different stakeholder groups. In contrast to the media analysis, qualitative interviews neither give an overview about the general public attitude towards the project nor display its relation to certain actions in the project, but they allow a close insight in personal perceptions and expectations of the participating individuals. Thus, by combining these methods one can both understand the current individual attitude of different stakeholder groups towards the project and identify relations to actions in the previous project history. Further, the interviews will help to identify the actual role of local newspapers in information and opinion forming for different stakeholder groups.

The interviews were problem-oriented and held in an open, semi-structured style with a guideline (Mayer 2013). The objective of the interviews was to find out the participants' (1) attitude towards the project; (2) stakeholder role and issues; (3) perception of transparency and communication within the project; (4) will to participate; and (5) attitude towards activities in the project context.

After every interview the participants were asked to recommend new interview partners, who in their opinion were important stakeholders in the Emscher mouth project, thus using the snowball principle (Biernacki and Waldorf 1981). As most participants did not agree to have their speech recorded, extensive notes were taken during the interviews. The content was then manually analysed (Mayring 2010).

In total, 13 semi-structured interviews were conducted in November 2015. The durations of the interviews ranged between 20 and $120 \mathrm{~min}$.

Four participants are residents of the settlement "Am Stapp". Two participants live close to the transportation route for soil. Two participants were visitors at the Emscher mouth (fishing/cycling). Three participants are leaders of local citizens associations ("Heimatverein Eppinghoven"; Citizen's initiative "Bergbaubetroffener") or political groups ("CDU Eppinghoven"). The representative of the citizens association "Heimatverein Eppinghoven" lives close to the transportation route at the "Konrad-Adenauer"-street and answered the questions both as a resident and as the leader of the local citizen's association. One participant represents the local nature conservation group ("NABU-Kreisgruppe Wesel"). Finally, two participants are officially involved in the project (EG).

The composition of the sample $(n=13)$ was structured as follows: four participants were female, and nine were male. The age structure ranged between 35 and 75 years.

Two participants also provided their personal archive documents collected during the project implementation period.

\section{Results}

To get the most benefits from the applied method mix the result section is structured as follows: the results of both media analysis and qualitative stakeholder interviews are directly compared concerning the public acceptance of (A) the course of events during the restoration of the Emscher mouth (chronologically) and (B) conducted public participation events.

\section{Course of events during the restoration of the Emscher mouth}

The plan to ecologically improve the Emscher mouth was presented in May 2007 at the city council of Dinslaken. In 2008, the plan was submitted to the approval authority (District Council Düsseldorf). In 2009, the legally required formal public participation took place in Dinslaken. In total, 18 statements of private stakeholders and 16 statements of public agencies were incorporated in the public hearing. While all of the people who participated in the interviews refer to it as "formally correct", they are not totally satisfied with the consideration of their claims in the approved plan. The amount of articles as well as its attitude shows both a high local relevance of the ecological improvement at the Emscher River's mouth and an ambivalent discussion among Dinslaken's inhabitants at this time (see Fig. 2).

After the formal public participation process the next step of the project that received media coverage was a change of plans that had to be submitted due to new hydraulic calculations in 2011. The revised plan requests a widening of the area between the dykes at the bridge Hagelstraße (see Fig. 3) to ensure resilient flood protection. In order to do so, the bridge and two houses north of the dyke (Hagelstraße 53 and 55) will have to be removed. After the conclusion of the project, a new bridge is supposed to be built. In the meantime the provisional crossing is passable for walkers and cyclists only. The EG was able to buy both properties at the Hagelstraße, thus avoiding conflicting interests. The inhabitants of the settlement "Am Stapp" expect restricted access to their properties because the detour, which they are now facing in order to reach their compounds, is a very small road (see Fig. 3). Furthermore, the inhabitants of the "Nordstraße" (see Fig. 3) have to give up $5 \mathrm{~m}$ of their gardens to make room for a dyke protection zone that has to be implemented. As the plan was only changed and not newly submitted, a second formal public participation was not compulsory and has not been conducted. After the announcement of the change of plans the new development was frequently covered by the local newspapers where it was discussed very critically 
(a) context-related timeline

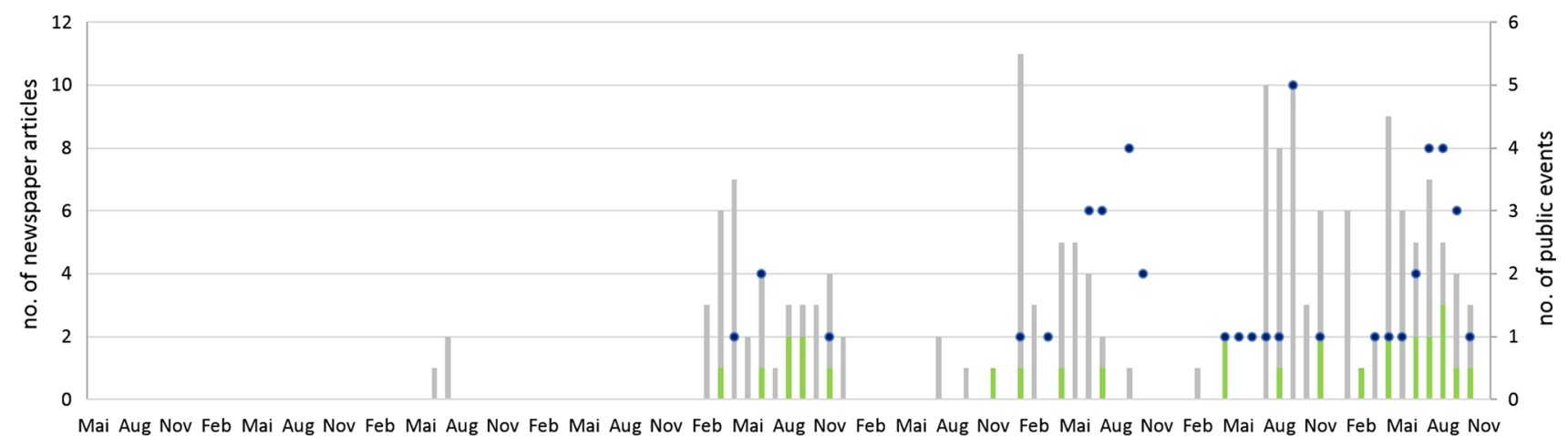

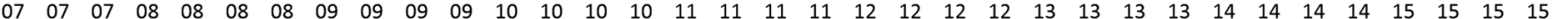

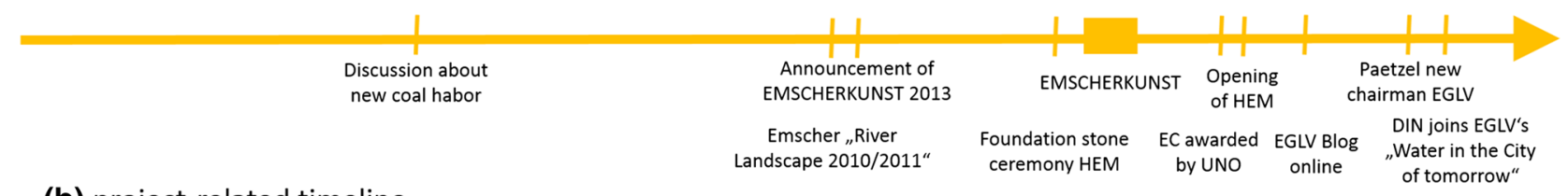

(b) project-related timeline

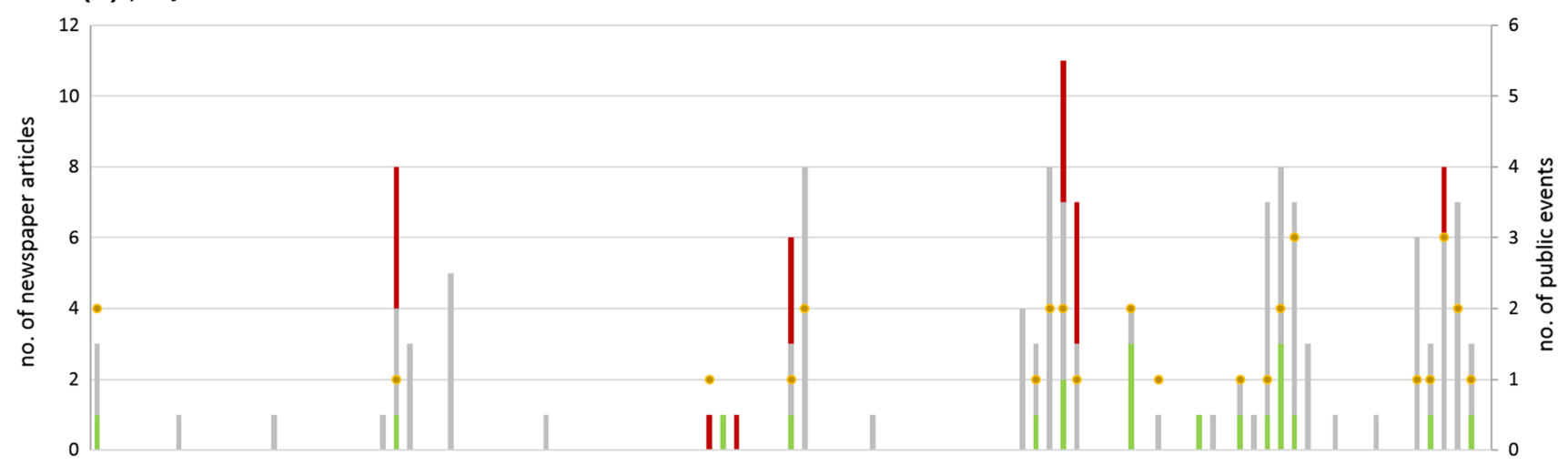

Mai Aug Nov Feb Mai Aug Nov Feb Mai Aug Nov Feb Mai Aug Nov Feb Mai Aug Nov Feb Mai Aug Nov Feb Mai Aug Nov Feb Mai Aug Nov Feb Mai Aug Nov

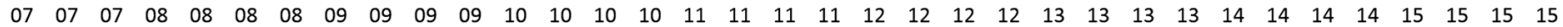

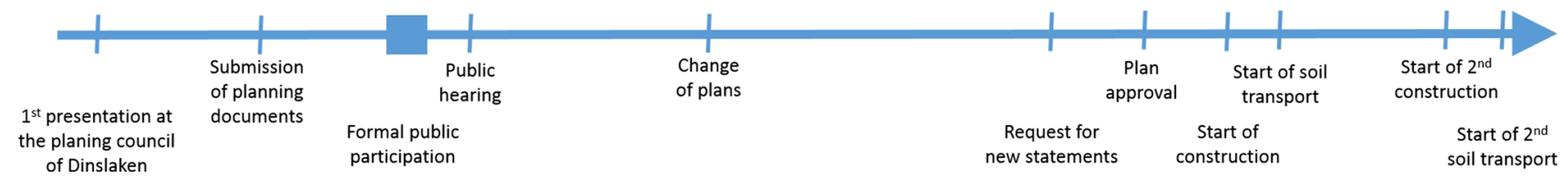

Fig. 2 The project's course of action a) associated with the Emscher Conversion in the projects river basin context (referred as contextrelated timeline) and b) explicitly related to the ecological improvement of the Emscher River's mouth (referred as project-related timeline). The bars represent the number of newspaper articles

(see Fig. 2). Statements of local opinion leaders were quoted. In particular, the deconstruction of the bridge and the delay that the change of plans entails for the project, were present in the articles. The affected parties in the interviews state that losing $5 \mathrm{~m}$ of their "cultivated gardens" for dyke protection zones is seen as a very drastic measure. "The development of new plants will take a long time". All residents of the settlement "Am Stapp" feel affected by the temporary destruction of the bridge "Hagelstraße". They expect issues when accessing their properties as the detour "is passing a difficult crossing". published in 1 month as well as their attitude towards the project. The dots represent the number of public events in one month. Events that were conducted over a longer period than 1 month were counted in every month as one event

Although new formal public participation was not necessary in the formal procedures, in early 2013, official stakeholders (e.g. the city of Dinslaken or the local nature conservation agency) were asked to formulate final statements concerning the submitted plans. In the project's course of events this process was most present in the local media (see Fig. 2). While at this time, pros and cons of the project were actively discussed in Dinslaken's local newspapers, 2 month later, when the plan was approved, all articles represent a positive or neutral attitude towards the ecological improvement towards the Emscher River's mouth. 


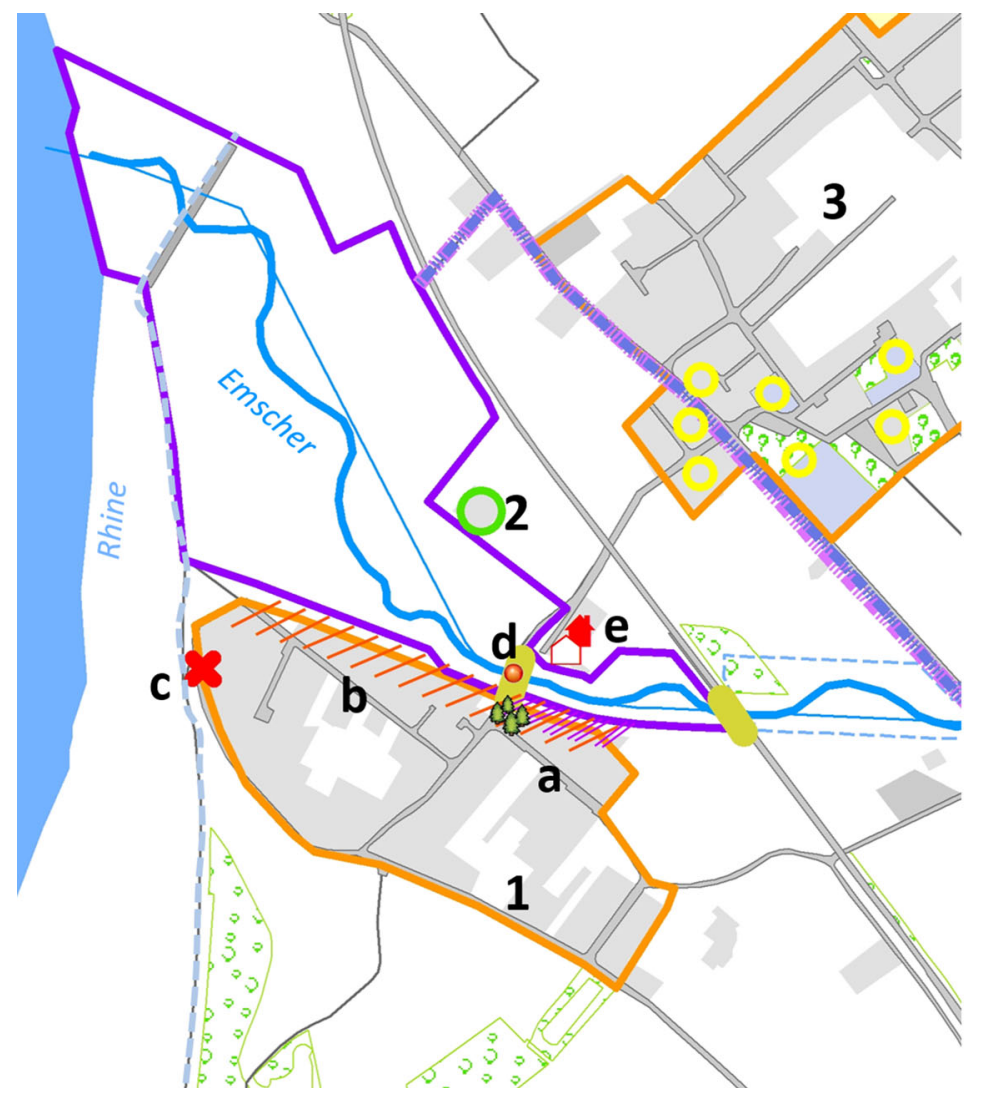

Legend:

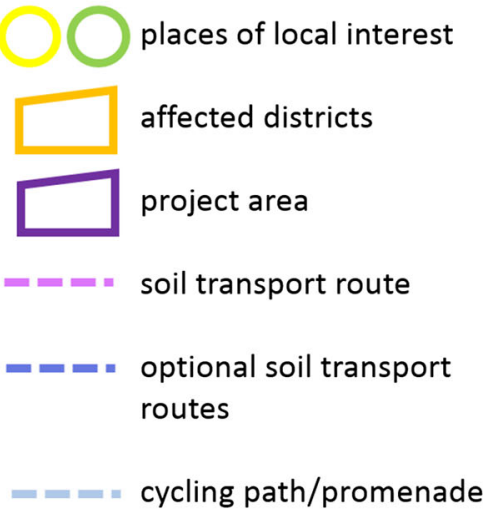

1. Settlement "Am Stapp"

a. Nordstraße

b. Rheinaue

c. "Haus Stapp“

d. Birdge Hagelstraße

e. Hagelstraße/Construction Office

2. Hof Emschermündung

3. Dinslaken Eppinghoven

Fig. 3 Detailed view of the project area and the neighbouring settlement "Am Stapp"

The interviews show that the overall attitude of the project in the region is positive. In particular, leaders of local associations describe it as "improving the value of the region" and as "attractive for tourism and local recreation". Also, the representative of a local citizen's initiative describes the restoration of the Emscher mouth as a "fantastic thing". Advanced functions of the new floodplains like "flood protection", "ecological connection to the Rhine", "decreased salt emission into the groundwater" or new "breeding and feeding habitats for birds" are often mentioned in combination with a positive statement. Since the late 1990s, salty water from the mining sector has been entering the groundwater because of leakages in the Emscher's river bed. Up to now, the residents are not able to use their groundwater wells. One resident of the street "Rheinaue" (see Fig. 3) explicitly agrees with the "objectives of the restoration measures". The project officials (EG) also feel this overall positive attitude towards their project. In general, they recognize that the public cherishes "big expectations". Conflicts are perceived as concerning only minor details.

Besides these positive attitudes, two participants of the settlement "Am Stapp" do not see any necessity for the implementation of the project. A dog-owning resident of the "Rheinaue" states that she is "very satisfied with the initial situation". Another resident ("Nordstraße") has the same opinion, as "many others, do too". "The formerly agriculturally used area is now transformed into a "moonscape". But he also implies the possibility of him changing his mind when the project will be finished. The fourth resident in the settlement "Am Stapp" sees a need for action (concerning the decrease of salt emission to the groundwater) but does not expect the project to be appropriate. A resident at the soil transport route ("KonradAdenauer-Straße", see Fig. 4) sees the project as a "waste of money" as he only expects the result to be "superficial and nice looking".

Participants, who are mainly visitors in the area, do not have such clear opinions towards the project. They perceive the changes as "interesting". The angler who regularly visits the Emscher mouth says that he is "satisfied with the current situation". For him, it is most important that the usability as a fishing ground is not restricted.

After the plan was finally approved in 2013, the first construction phase was initiated in spring 2014. During the entire project implementation, ca. $1.3 \mathrm{Mio}^{3}$ of soil has to be removed from the project area in two phases (2014 and 2015) by trucks. An overview of the entire project environment and the transportation route can be seen in Fig. 4. During the first phase of soil transportation, there was a 


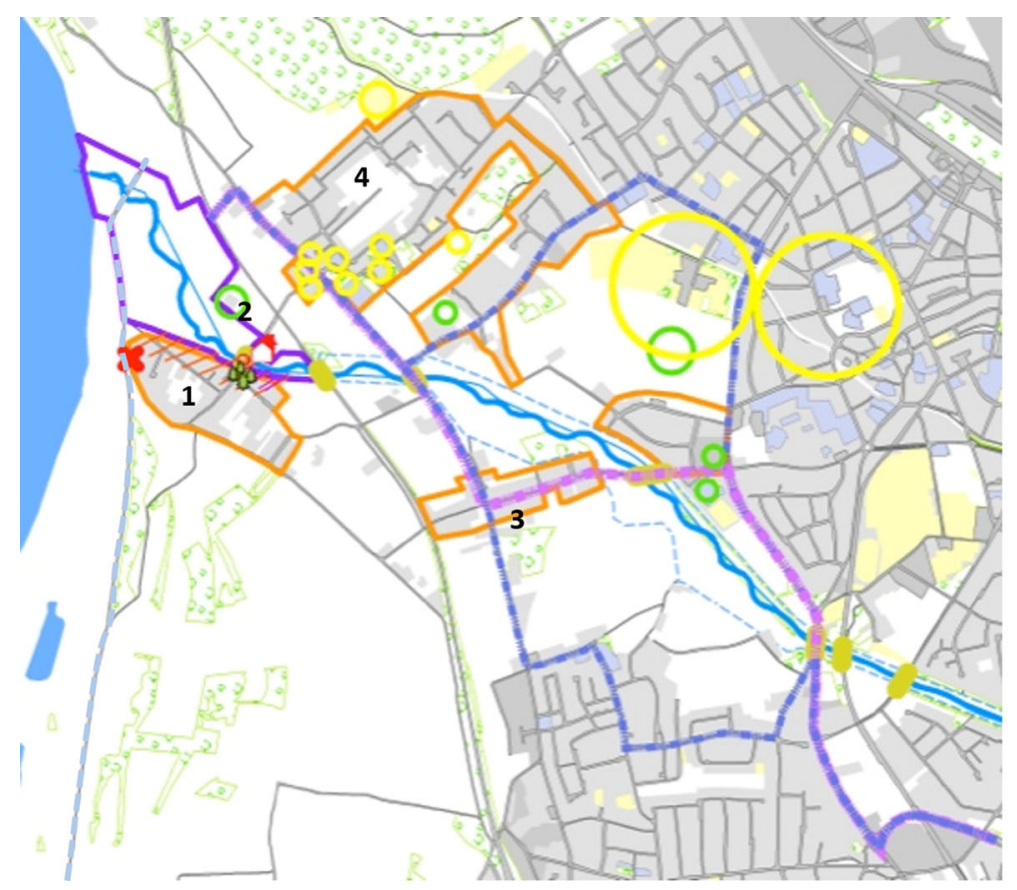

Legend:

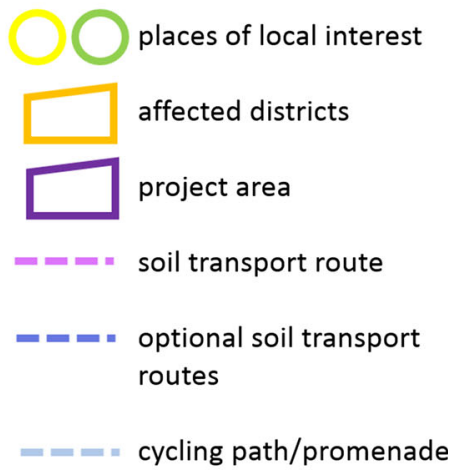

1. Settlement "Am Stapp“

2. Hof Emschermündung

3. Konrad-Adenauer-Straße

4. Dinslaken Eppinghoven

Fig. 4 Overview of the results of the environmental analysis around the project area

quite intense media coverage implying a neutral or positive local public attitude towards the project (see Fig. 2). Despite this, the leaders of local associations and politic groups are aware of the effects that the project has on the residents. While the traffic along the soil transportation route is assessed as "acceptable" because it is "only" temporary, the residents fear the "safety of their children", "noise disturbance" and "damages of streets and their properties". The leader of the local political group stated that she feels like "the rest of birds is valued higher than the rest of people". To indicate this, the residents have formed a citizen's initiative, counted the actual amount of transporter vehicles per day and sent a complaint with more than 70 signatures to the city of Dinslaken.

In general, long-term concerns of the residents of the settlement "Am Stapp" are perceived as the most drastic of all participants. Inhabitants of the "Nordstraße" (see Fig. 4) fear losing their "privacy", "quality of life" and "feeling of safety" as the Emscher dykes will be opened for the public and scrubs and trees have to be cleared. They expect increasing opportunities for possible housebreakers to spy on their properties and, besides visual impairments, noise disturbance by users and increased pollution consisting of left behind waste and dog excrements. Residents right behind the Emscher dyke in the street "Rheinaue" expect "drastic disturbance" due to "smell emissions from standing waters with faecal residues from the WWTP Emschermündung after storm water events" and "pests of rats and midges". In their opinion, there are "no appropriate plans for these scenarios". This is recognized as especially dangerous for residents who are allergic to these animals. Pesticides are not seen as feasible means to control these pests as one participant fears that it "could heavily affect the environment".

Residents, representatives and visitors of the area expect that the sealing of the Emscher bed will prevent further trickling of salt-polluted water into the groundwater.

\section{Public participation}

Since the official announcement of the project in 2007, 67 public events were carried out in the area. The intention was either to inform $(n=27)$ or to boost identification with the overall project $(n=40)$. Main organizers on official level were the EG and the city of Dinslaken. In addition, local associations, political groups, nature conservation agencies and public institutions organized public events (the totality of these groups is referred to as "others" in Figs. 5, 6, 7). Four events, which the EG organized, were both an attractive leisure activity and a possibility for local people get information on the project; therefore, those events were counted in both categories. If an event is open to everybody, it is referred to as "general public" in Figs. 5, 6, and 7. If only a certain group of people is invited (e.g. members of the organizing association), a "selected public" is targeted. Some events were only meant for "representatives" of political groups or other official associations. Meetings in the city council of Dinslaken that were also open to the public were counted as "representatives and general public". Overall, 
$60 \%$ of all public events were organized for the "general public".

Figure 5 shows the proportion of public participation activities explicitly organized with relation to the ecological improvement of the Emscher River's mouth (referred to as project-related public events) and those transferred from the accompanying campaign associated with the Emscher Conversion in the project's river basin context (referred as context-related public events) as well as the specific target groups.

\section{Project-related situation}

Twelve of the 23 public events that were exclusively related to the project were organized by "others". Seven events were initiated by the city of Dinslaken and five by the EG. The four events organized by the city of Dinslaken for "representatives and the general public" were open city council meetings that dealt with decisions concerning the project. The events organized by the "others" were for instance a meeting of the local political group "CDU Eppinghoven" where a guest speaker of the EG was invited to. Some of these meetings were open to the "general public".

Taking the timescale into account, most events organized by project officials were conducted after the planning approval in 2013. One arrives at the conclusion that the official agents waited until the plans had been approved before reaching out to the "general public". Figure 5 illustrates that the EG acts rather passively: instead of organizing events by themselves, they are more often invited by other agents. Still, in 2014, the EG renovated an unmaintained farm in the project area which now functions as an information centre: at the "Hof Emschermündung", there is a permanently updated exhibition concerning the project. Figure 6 gives an overview of the organizers of the exclusively project-related events and their target groups.

Most public events were announced in the local newspapers. Information meetings concerning the ecological improvement of the Emscher River's mouth where the EG acted as organizer or involved party were also covered with reports presenting new information and statements of participants and EG. The majority of these reports were assessed as neutral since both positive and negative statements were given.

Most of the participating residents and visitors in the area collect their information about the project mainly from the local newspapers NRZ and RP. While the residents are very well informed and partly even collect all articles in personal archives, visitors state that they "didn't put enough effort" into informing themselves and that they "are not satisfied with that" but have not had the time. "Dinslaken is a relatively rural area and people are very well connected", is the perception of the project leader. Indeed, one resident of the settlement "Am Stapp" refers to another resident as an "expert in this topic". "He is providing all people here with information".

Interview participants think that the EG aims to "answer questions and incorporate wishes where possible" during their information meetings. Two of six participants that
Fig. 5 Overview of the target groups of project- and contextrelated public events in the framework of the restoration of the mouth of the Emscher. The numbers show the amount of events

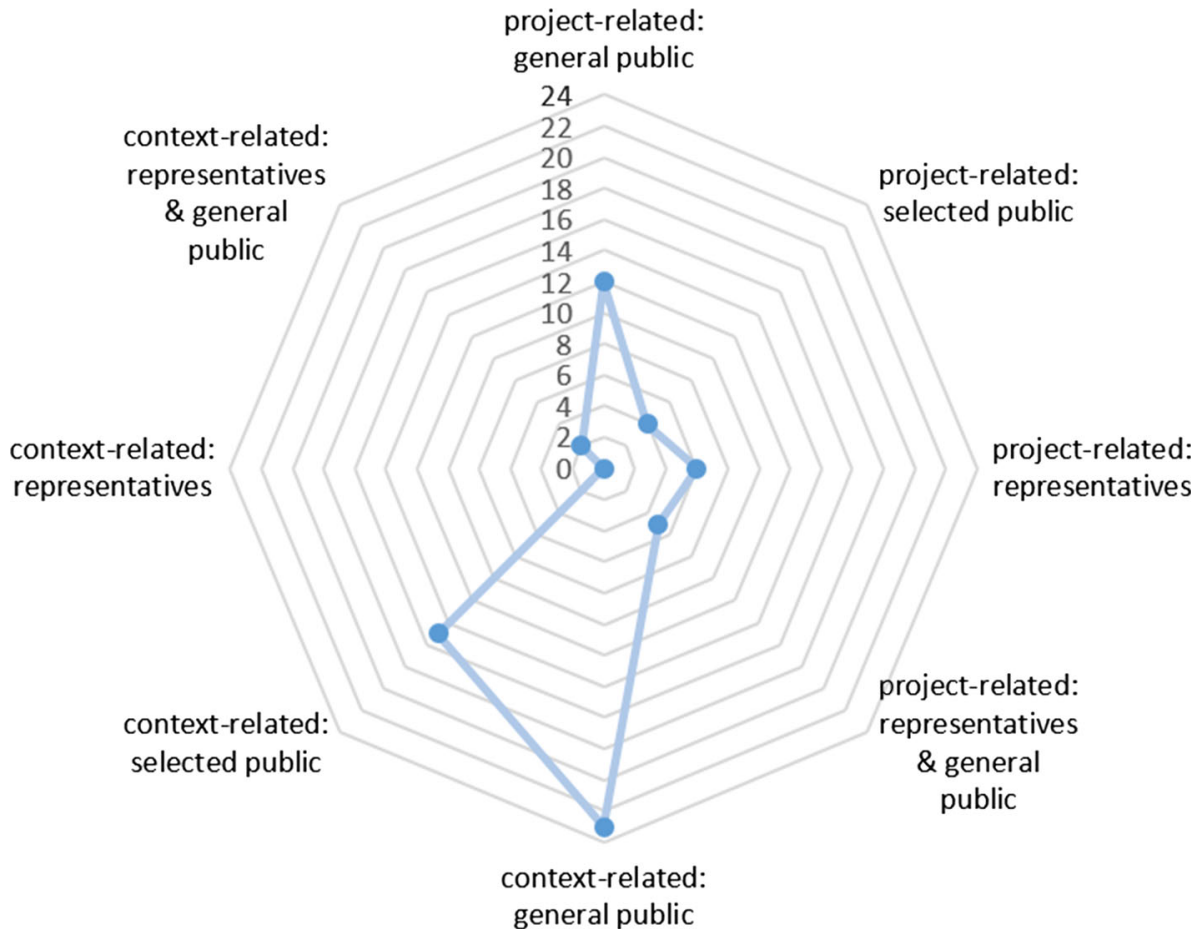



the EG, the city of Dinslaken and others (public associations, agencies or local political groups) in the organization of public events that are directly related to the project and the target groups. The numbers show the amount of events
Fig. 6 Overview of the role of
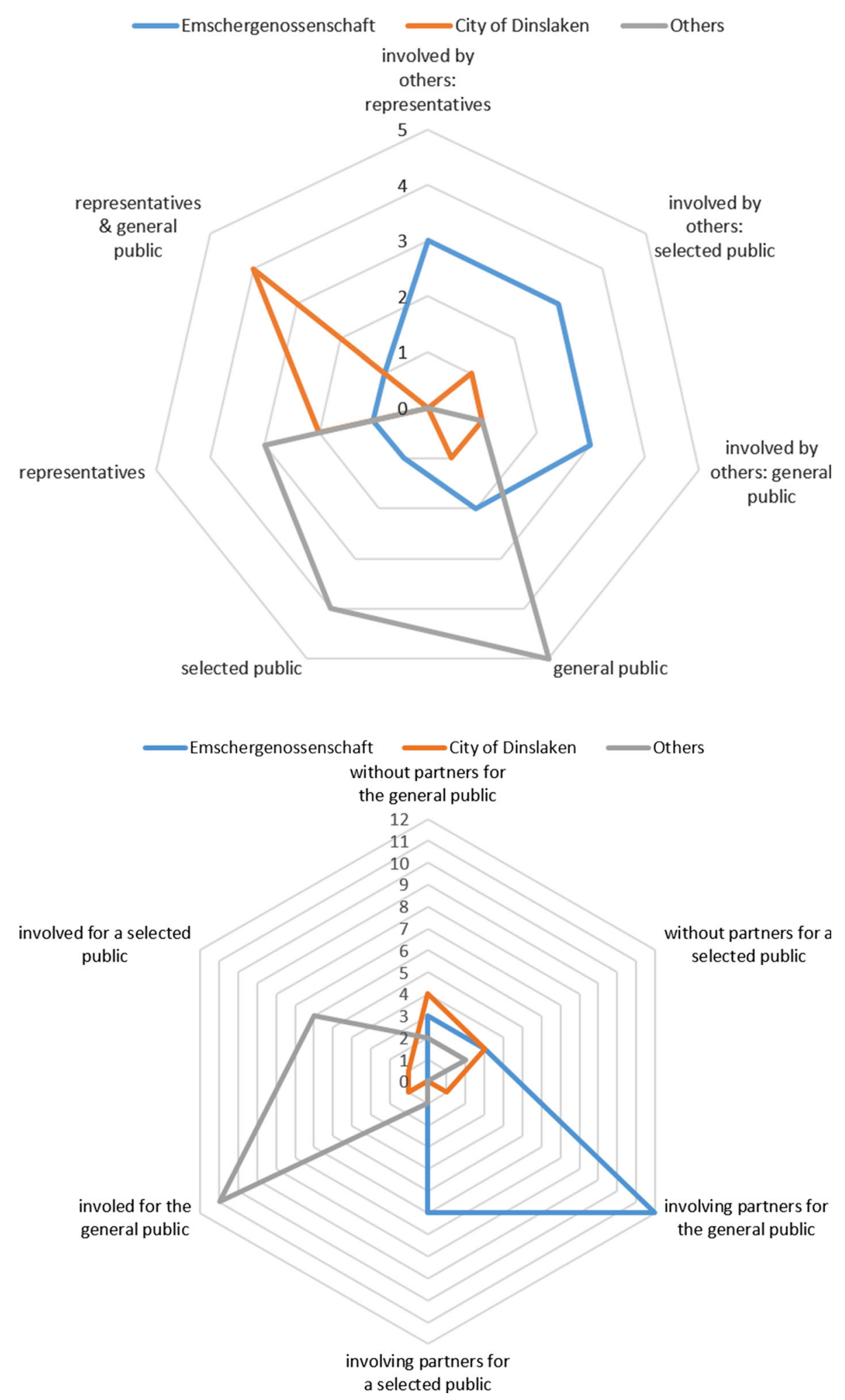

Fig. 7 Overview of the role of the EG, the city of Dinslaken and others (public associations, agencies or local political groups) in the organization of public events that are related to the project's context and the target groups. The numbers show the amount of events

perceive themselves as affected by the project visit official information meetings organized by the EG and/or the city. "Information does not change anything", "everything is fixed, anyway", one resident of the settlement "Am Stapp" states. A resident of the "Konrad-Adenauer-Straße" is claiming that "the communication with the responsible party leaves a lot to be desired". He was informed about the transports "by newspaper two days before". In his opinion, the people responsible were only considering communication, when he "initiated a contact". "These few 
people here" are not important enough, he presumes. Also, a resident from the settlement "Am Stapp" criticizes the EG's lacking will to communicate, as promenades around the project area were "blocked overnight without any info".

The representatives of associations and local political groups perceived the EG as "very cooperative". "CDU Eppinghoven" and the "Heimatverein Eppinghoven" invited representatives of Dinslaken and EG to their internal meetings. The participant from the nature conservation agency reported "very informative (not public) meetings with presentations and discussion" where the EG offered to inform NABU members about the project.

Although public participation concerning the project to ecologically improve the Emscher River's mouth was limited to information and one formal consultation during the early state of the plan approval process, the interview participants are not demanding higher empowerment. "Because of the overall positive perception of the project, the interest in public participation is low", states the leader of a local association. Additionally, also one of the residents of the "Rheinaue" is convinced that "the general public is not very interested" and that "there is only a chance to really change something if a bulk of people is going to protest". Indeed, one of the visitors states that "public participation is always good" but she does not have "the time to get involved in this case".

Also, the residents and representatives of local groups do not request any other form of public participation in decision-making. In their opinion formal public participation within the plan approval procedure is sufficient. Two residents of the settlement "Am Stapp" were actually participating, and two local group leaders were supporting residents of this settlement in the formal public participation process. All state that the process was "correct", but also that the required announcements in the newspaper can "easily be missed" and totally "exclude people who are not using this type of media". The residents of "Nordstraße" and "Konrad-Adenauer-Straße" claim that their objections were emerging with the developments, so that they were "not aware of the problems at the period of formal public participation". "From today's point of view, I would absolutely participate". However, "the plan has already been approved and now you cannot do anything anymore". This kind of resignation is shared among all affected residents. Also, the change of plans without any further formal public participation is seen critically.

One of the residents was representing a local nature conservation agency (NABU) in the beginning of the approval process. She perceived that in this position, she "had much more rights in the decision-making. The possibilities to participate as an ordinary citizen are highly limited". The representative of the nature conservation agency regards early and active public participation as "definitely worthwhile".

In general, all participants would rate accurately timed and comprehensive information and open communication as more important for their acceptance of the ecological improvement of the Emscher River's mouth than active public participation in decision-making.

\section{Context-related situation}

The EG is the active agent in organizing context-related events and often includes public institutions or groups (see Fig. 7). Context-related events are either related to the area in proximity of the new mouth of the Emscher River or transferred from the accompanying campaign associated with the Emscher Conversion in the project's river basin. A large majority of these events target the "general public". Examples are events held at the "Hof Emschermündung" (information centre) or "EMSCHERKUNST" (an open-air art exhibition in the project area). Other activities are aimed at certain target groups, e.g. schools, local sport clubs or kindergartens. Examples of these types of events are the annual "Emscher-Junior-Cup" (a soccer tournament for junior teams along the Emscher) or "Zauberwelt Wasser" (an educational programme for children from age five to ten). Both types of events are implemented within the context of restoration projects alongside the entire Emscher river system. Besides its function as an information centre, the "Hof Emschermündung" also accommodates a café ("Mats \& Mia"), an educational project that explains ecological coherencies ("sevengardens"), a bike rental outlet ("RevierRad"), a beekeeping association ("Imkerverein Dinslaken") and the local nature conservation group ("NABU"). Therefore, it attracts the general public that would normally neither get in touch with the ecological improvement of the Emscher River's mouth nor the Emscher Conversion.

The city of Dinslaken is less active in organizing these types of public events. One example is Segway Tours in the area around the Emscher mouth. These tours focus less on informing about the project but are more geared towards recreational purposes.

Figure 2 gives an overview of context-related events, taking the timescale into account. If events take place over a longer period than 1 month, they are counted in every month.

In particular, cultural or educational events were highly recognized in the local newspaper and generate a positive attitude towards projects at the Emscher River's mouth, the Emscher Conversion and the EG itself. Most prominent was the planning and implementation phase of EMSCHERKUNST. Newspaper issues or articles announcing or reporting of these events often also provide 
information about the local and regional progress of Emscher Conversion. Further it is noticeable that the amount of these articles is increasing, while the local perceptibility of the project becomes more evident, for example, with the beginning of soil transports.

All participants know that the restoration of the Emscher River's mouth is part of the larger Emscher Conversion. Different to the knowledge about the local project, the affected residents do not feel "well informed" about the Emscher Conversion. Interestingly, they named newspaper articles as their main source of information, but also different forms of information at the "Hof Emschermündung" or the internet presence of the EG. "The Emscher Conversion does not affect my acceptance of the Emscher mouth project", one resident of the "Rheinaue" states. The representative of the nature conservation agency sees the new Emscher mouth as the "eye-catcher project of the entire Emscher Conversion". "This big space will be a visible sign for citizens and tourists. Here, they will realize how the "Köttelbecke" [local nickname for the Emscher as open sewer] becomes nature".

Public events like "EMSCHERKUNST" that are not directly related to the project are perceived as "somewhat exaggerated" or "wasted money that could better be invested in something useful" by affected residents and two group leaders. But one resident also sees these public events as "image enhancements" and "a plus" for the recognition of "some citizens". Besides, the leader of the political group and the officials of the project think that there was "no direct relevance for the project", but "it was well accepted" and "people came from everywhere".

Infrastructural measures in the context of the project, like the "Hof Emschermündung" or the cycle routes along the Emscher, are generally perceived as "good for Dinslaken". Also the context-related media analysis did not find any article implying a negative attitude towards the ecological improvement of the Emscher River's mouth.

\section{Discussion}

The combination of a local media analysis and qualitative stakeholder interviews allows a new way of assessing the relations between public acceptance and a project's course of actions including public participation. Overall the statements of the interview participants validate the importance of local newspaper as primary source of information in this particular rural area. Therefore, the methodological approach enables both an unbiased analyses of the direct public reaction to certain steps during the course of the project and detailed insights in the individual attitudes of local stakeholders towards river restoration. Thus, it is possible to draw a connection between public acceptance and certain forms of public participation. Furthermore, the case study gave the opportunity to assess the different impact of public participation at subordinated project scale and the superordinate river basin scale as well as synergistic effects of both on the local stakeholders' individual and the overall public acceptance.

The inhabitants of Dinslaken and its surroundings have a long troublesome history of clashing interests with the mining sector as well as with the operators of the local coal-fired power plant. Therefore, they have a very high expertise in how to participate in approval procedures and have built up a well-structured protest network. Also, they are very sensitive to changes in their environment. Compared to other parts of the Emscher system, the river section downstream from the WWTP "Emschermündung" was never really an "open sewer", since all water was being treated by the plant. According to the residents, smell nuisance can only be recognized in very warm and dry weather periods, when there is no water current. This circumstance is unique in the context of the Emscher Conversion. The starting point for the ecological improvement of the Emscher River's mouth is not an open sewer, but an area that residents perceive as being relatively close to nature and that is already used for recreation. Therefore, it is to highlight that the residents of Dinslaken have to accept changes that are not primarily linked to problems in their direct surrounding but to improvements in the upstream part of the Emscher river basin.

All these factors indicate that the local population tends to be especially sceptical towards changes in their environment. Although readiness to changes is an important variable for acceptance (see Fig. 1) and some of Dinslaken's residents are facing recognizable interference with their everyday lives, there is an overall positive attitude towards the project. An important advantage for the project was the fact that there was no privately owned land in the area. All land was held by the "RAG Montan Immobilien GmbH". Therefore, the EG was able to buy the entire project area without having to negotiate with private land owners. Conflicts arising from private land ownership are typically the most hindering factors for river restoration projects (Völker 2014), as they are one of the most significant impairments influencing the individual acceptance of local stakeholder (see Fig. 1). Some impairments are only of temporary nature (e.g. traffic at the "KonradAdenauer"-street). Others cause a permanent loss of life quality for local residents. For these people, it is very difficult to accept the project, since they have not experienced any benefits, so far. As most of them were not recognizing any inconvenience with the original situation, they also would not necessarily see any improvements in future. 
In the interviews, one resident of the "Rheinaue" states that the way that the project is being carried out "is just not fair!". The residents feel that they are neglected by project officials. Still, they think that "public participation will change nothing, the plans are fixed". Indeed, in the context of the Emscher Conversion, the plans for every project are more or less unalterable, and thus, there is little room to negotiate alternatives. Since the plans are already fixed, the EG does not offer any chance to participate in the decisionmaking process. Therefore, their project-related public events are for informational purposes only. In this case real public participation is not possible anyway and local residents who are impaired by the changes get the impression that it is nothing but a token gesture.

Compared to the overall population, the number of highly affected stakeholders is relatively small. Still, due to the fact that the local population is very well connected and also due to the importance of local newspapers for the formation of public opinion, few people can have a great impact on the overall acceptance of the project.

To mitigate this effect, the EG applies a strategy where they mainly focus on winning the minds of the broader public in the project's context instead of only reaching out to the few locals who are most impaired by their project (compare Fig. 6 and 7). Still, the EG tries to stay in direct contact with the most affected residents. As acceptance can be influenced by the readiness to change and a trustful relation (see Fig. 1), continuous communication and transparency can be a mitigating aspect. Thus, it is possible to have different degrees of individual acceptance among the local stakeholders and boost the overall public acceptance. Furthermore, this strategy prevents unfavourable or biased media coverage (see Fig. 2). This can also be recognized in the overall high amount of newspaper articles covering the topic of the Emscher Conversion and the ecological improvement of the Emscher River's mouth. An active press department at the EG provides the local media with statements, event announcements and reports. In particular, the articles that are not directly related to the local project mitigate the influence of negative articles on the public opinion forming process.

Since the motivation to participate in any event correlates with the degree of concern, the public has to be "activated" to overcome the so-called participation paradox (Roßnagel et al. 2014). The EG's strategy consists of two activating steps: (1) offering events that are both attractive for the general public and simultaneously convey information on the project (e.g. four citizen's festivals at the Emschermündungshof) and (2) using already existing social structures by involving local associations (e.g. sport clubs for the "Emscher-Junior-Cup") and public institutions (e.g. schools or kindergartens for "Emscher-Kids" or “Zauberwelt Wasser”) (see Fig. 7).
By applying this double strategy in the whole Emscher Region, the EG encourages a sense of regional solidarity. This has two main consequences: first, citizens are starting to get familiar with the project and identify with its objectives. This creates an overall feeling of participation. Second, one of the main objectives of the Emscher Conversion to enhance the region's reputation is perceived as an overall public benefit that increases the readiness for change. Both factors are significantly influencing the overall public acceptance (see Fig. 1) of the Emscher Conversion on river basin scale and transfer of a high general legitimacy for the single measure on the local scale.

\section{Conclusion}

Although one could argue that the conversion of a malodorous, open sewer system into a close-to-natural river should be easy to communicate to the public, the Emscher Conversion's image as an example for a working big infrastructure project in Germany is also the result of continuous investments in an extensive accompanying communication concept that is transferred to the single restoration projects as presented in the case study. The perception of personal concern is also significantly influencing the personal acceptance of local stakeholders (see Fig. 1). Main reasons for personal acceptance of the project were for example: having access to transparent information, the preservation of the former benefits for the economic and ecological development of the region. If the disadvantages of a project exceed the personal and general advantages for a stakeholder, he/she is not likely to endorse it. Public participation or events that are promoting the supra-regional context are not likely to change these people's minds. But continued communication and a feeling of transparency adjusted to the needs of different local stakeholders might mitigate personal impairments to a certain degree. In sum, the EG offered no room to negotiate or many chances for citizens to participate and did not start their information sessions before the finalization of the planning approval (see Fig. 2). But nonetheless, there is a common perception of the project that is resilient to local opinion forming processes.

The restoration of an entire river system in the framework of one big project is unique and gives the opportunity to systematically match activities on river basin and project scale. The synergetic effects can guarantee regional legitimacy due to the common identification with the project and its context as well as immediate interaction with local momentum, but not a mutual acceptance of all affected stakeholders.

Further research could address the question how the active press work of the EG might influence the attitude of 
the local media coverage towards this single project and the entire Emscher Conversion. Also, it would be worthwhile to study other projects alongside the Emscher system to evaluate the findings of this single case study.

Acknowledgments This study was performed within the Fortschrittskolleg FUTURE WATER and funded by the Ministry of Innovation, Science and Research NRW. FUTURE WATER is coordinated by the "Zentrum für Wasser- und Umweltforschung" (ZWU) under the direction of Simon Kresmann and Dr. Michael Eisinger. English editing was conducted by Maximilian Kunstleben, Thomas Höller and Stephanie Grandrath.

\section{Compliance with ethical standards}

Conflict of interest The authors declare no conflict of interest.

Open Access This article is distributed under the terms of the Creative Commons Attribution 4.0 International License (http://crea tivecommons.org/licenses/by/4.0/), which permits unrestricted use, distribution, and reproduction in any medium, provided you give appropriate credit to the original author(s) and the source, provide a link to the Creative Commons license, and indicate if changes were made.

\section{References}

2000/60/EC. "Directive 2000/60/EC of the European Parliament and of the Council establishing a framework for the Community action in the field of water policy". http://eur-lex.europa.eu/ legal-content/EN/TXT/?uri=CELEX:32000L0060. Accessed 18 Dec 2016

Albrecht J (2013) The Europeanization of water law by the Water Framework Directive: a second chance for water planning in Germany. Land Use Policy 30(2013):381-391. doi:10.1016/j. landusepol.2012.04.009

Arnstein SR (1969) A ladder of citizen participation. J Am Inst Plan 35(4):216-224

BDI (Bundesverband der Deutschen Industrie e.V.) (2011) Positionspapier: Die Zukunft von Infrastrukturprojekten - Akzeptanz steigern, Vorgaben, Beschleunigen, Planung vorantreiben. Industrie-Förderung $\mathrm{GmbH}$, Berlin

Beierlie TC (2002) The quality of stakeholder-based decisions. Risk Anal 22:739-749. doi:10.1111/0272-4332.00065

Bertelsmann Stiftung (2013) Mehr Transparenz und Bürgerbeteiligung-Prozessschritte und Empfehlungen am Beispiel von Fernstraßen, Industrieanlagen und Kraftwerken. http://www. bertelsmann-stiftung.de/fileadmin/files/Mehr_Transparenz_und_ Buergerbeteiligung.pdf. Accessed 16 Dec 2015

Bherer L, Breux S (2012) The diversity of public participation tools: complementing or competing with one another? Can J Polit Sci 45(2):379-403. doi:10.1017/S0008423912000376

Biernacki P, Waldorf D (1981) Snowball sampling: problem and techniques of chain referral sampling. Sociol Methods Res 10:141-163

BMVI (Bundesministerium für Verkehr und digitale Infrastruktur) (2014) Handbuch für eine gute Bürgerbeteiligung_Planung von Großvorhaben im Verkehrssektor. https://www.bmvi.de/Share dDocs/DE/Anlage/VerkehrUndMobilitaet/handbuch-buergerbe teiligung.pdf?_blob=publicationFile. Accessed 16 Dec 2015

Buijs AE (2009) Public support for river restoration. A mixed-method study into local residents' support for and framing of river management and ecological restoration in the Dutch floodplains.
J Environ Manage 90:2680-2689. doi:10.1016/j.jenvman.2009. 02.006

Büro der Zukunft (2014) Bürgerräte in Vorarlberg. Eine Ziwschenbilanz. https://www.vorarlberg.at/pdf/kurzfassungbuergerrae tezw.pdf. Accessed 15 Mar 2016

Collins K, Blackmore C, Morris D, Watson D (2007) A systematic approach to managing perspectives and stakeholding in water catchments: some findings from three UK case studies. Environ Sci \& Policy 10 (2007):564-574. doi:10.1016/j.envsci.2006.12. 005

Connif R (2014) Rebuilding the natural world: a shift in ecological restoration. Yale Environmental 360. http://e360.yale.edu/feature/ rebuilding_the_natural_world_a_shift_in_ecological_restoration/ 2747/. Accessed 20 Dec 2015

de Groot WT (1998) Problem-in-context-a framework for the analysis, explanation and solution of environmental problems. In: Nath B, Hens L, Compton P, Devuyst D (eds) Environmental management in practice, vol I., Instruments for environmental managementRoutlegde, London, pp 187-208

de Groot WT, van der Nat A (2011) Two cases of public participation in the Netherlands and the U.S.: learning from deductive and inductive analysis. In: de Groot WT, Warner J (eds) The social side of river management. Environmental science, engineering and technology. Nova Science Publishers Inc, New York, pp 55-74

DWA (2008) Aktive Beteiligung fördern!-Ein Handbuch für die bürgernahe Kommune zur Umsetzung der Wasserrahmenrichtlinien. DWA Deutsche Vereinigung für Wasserwirtschaft, Abwasser und Abfall e. V., Hennef 2008

Erhard J, Lauwers S, Schmerz S (2013) Do unconventional forms of citizen participation add value to the quality of democracy in Germany? A case study of the Bürgerdialog Energietechnologien für die Zukunft. In: Römmele A, Banthien H (eds) Empowering Citizens-Studies in Collaborative Democracy. Nomos Verlagsgesellschaft, Baden-Baden, pp 17-106

Farrell KN, van den Hove S, Luzzatti T (2012) Beyond Reductionism: a passion for interdisciplinarity. Routledge, London

Hennecke HJ, Kronenberg V (2014) Großprojekte als unternehmerische und politische Herausforderung. http://www.bapp-bonn.de/medien/ downloads/publikation_forschungsergebnisse/Groprojekte_als_ unternehmerische_und_politische_Herausforderung.pdf. Accessed 16 Dec 2015

Hermelink A (2008) Ein systemorientierter Beitrag zur Entwicklung einer nachhaltigkeitsgerechten Technikbewertung angewandt auf den mehrgeschossigen Wohnungsbau im Niedrigstenergie-Standard. Kassel University Press $\mathrm{GmbH}$, Kassel

Hildebrand J, Rau I, Schweizer-Ries P (2012) Die Bedeutung dezentraler Beteiligungsprozesse für die Akzeptanz des Ausbaus erneuerbarer Energien-Eine Umweltpsychologische Betrachtung. Informationen zur Raumentwicklung 9:491-501

Hillebrand H, Beun N, van den Herik K, van Rooy P (2011) Building new rivers: a case study from the Netherlands. In: de Groot WT, Warner J (eds) The social side of river management. Environmental science, engineering and technology. Nova Science Publishers Inc, New York, pp 113-128

Hitschfeld U, Lachmann H (2013) Akzeptanz als strategischer Erfolgsfaktor. Friedrich-Ebert-Stiftung, bub Bonner Universitäts-Buchdruckerei, Bonn

IDA (Institut für Demoskopie Allensbach) (2011) Akzeptanzprobleme großer Infrastrukturprojekte-Ergebnisse einer bundesweiten Repräsentativumfrage. Allensbach am Bodensee. http://www.baustoffindustrie.de/root/img/pool/downloads_2011/ 130911/text_handout_koecher.pdf. Accessed 18 Dec 2015

Jager NW, Challies E, Kochskämper E, Newig J, Benson D, Blackstock K, Collins K, Ernst A, Evers M, Feichtinger J, Fritsch O, Gooch G, Grund W, Hedelin B, Hernández-Mora N, 
Frank H, Huitema D, Irvine K, Klinke A, Lange L, Loupsans D, Lubell M, Maganda C, Matczak P, Parés M, Saarikoski H, Slavíková L, van der Arend S, von Korff Y (2016) Transforming European water governance? Participation and river basin management under the EU water framework directive in 13 member states. Water 8(4):156. doi:10.3390/w8040156

Jax K, Barton DN, Chan KMA, de Groot R, Doyle U, Eser U, Görg C et al (2013) Ecosystem services and ethics. Ecol Econ 93:260-268

Karlsen JT, Mona KG, Massaoud J (2008) Building trust in projectstakeholder relationships. Balt J Manag 3(1):7-22. doi:10.1108/ 17465260810844239

Kastens B, Newig J (2008) Will participation foster the successful implementation of water framework directive? The case of agricultural groundwater protection in Northwest Germany. Loc Environ 13(1):27-41

Lindemann M (2011) Three dimensions of place attachment: bonds with the Rhine and Elbe rivers. In: de Groot WT, Warner J (eds) The social side of river management. Environmental science, engineering and technology. Nova Science Publishers Inc, New York, pp 27-40

Lucke D (1995) Akzeptanz-Legitimität in der „Abstimmungsgesellschaft". Springer Fachmedien, Wiesbaden

Luyet V, Schlaepfer R, Parlange MB, Buttler A (2012) A framework to implement Stakeholder participation in environmental projects. J Environ Manage 111:213-219. doi:10.1016/j.jenvman. 2012.06.026

Mayer HO (2013) Interview und schriftliche Befragung-Grundlagen und Methoden empirischer Sozialforschung. Oldenbourg Wissenschaftsverlag $\mathrm{GmbH}$, München

Mayring P (2010) Qualitative Inhaltsanalyse: Grundlagen und Techniken. Beltz Verlag, Weinheim \& Basel

Muro M (2002) Zur Wirksamkeit der Öffentlichkeitsbeteiligung von wasserwirtschaftlichen Planungen in Deutschland. Technische Universität Berlin. Consensus Conference-Manual

Newig J (2005) Die Öffentlichkeitsbeteiligung nach der EG-Wasserrahmenrichtlinie: Hintergründe, Anforderungen und die Umsetzung in Deutschland. Zeitschrift fur Umweltpolitik und Umweltrecht 28(4):469-512

Newig J, Fritsch O (2009) Environmental governance: participatory, multi-level—and effective? Environ Policy Gov. 19(3):197-214

Nielson AP, Hansen J, Skorupinski B, Ingensiep HW, Baranzke H, Lassen J, Sandoe P (2006) Consensus conference-manual. http://www.moraltheologie.uni-wuppertal.de/wp-content/uploads/ 2014/11/ET4-Manual-CC-Binnenwerk-40p.pdf. Accessed 20 Dec 2015

Oosthuizen M (2006) An evaluation of a public participation process for fairness and competence, University of Johannesburg (Minor-Dissertation)

Özerol G, Newig J (2008) Evaluating the success of public participation in water resources management: five key constituents. Water Policy 10(6):639-655

Pust M (2014) Akzeptanzkommunikation der Energiewende. DGMK/ ÖGEW-Frühjahrstagung 2014, Fachbereich Aufsuchung und Gewinnung Celle, 24./25. April 2014. http://www.dgmk.de/ upstream/Abstracts_Celle14/08_Pust.pdf. Accessed 18 Dec 2015
Reicher C, Kunzmann KR, Polívka J, Roost F, Utku Y, Wegener M (2011) Schichten einer Region. Jovis, Berlin

Renn O, Webler T, Wiedermann P (1995) Fairness and competence in citizen participation: evaluating models for environmental discourse. Kluwer Academic Publishers, Berlin

Roßnagel A, Ewen C, Götz K, Hefter T, Hentschel A, Huge A, Schönfelder C (2014) Mit Interessengegensätzen fair umgehenzum Einbezug der Öffentlichkeit in Entscheidungsprozesse zu dezentralen Energieanlagen. Zeitschrift für Neues Energie Recht 4:329-337

Skodra J (2014) Emscher conversion and quality of life. 50th ISOCARP Congress 2014: 1347-1358

Skorupinski B, Baranzke H, Ingensiep HW, Meinhardt M (2007) Consensus conferences-a case study: PubliForum in Switzerland with special respect to the role of lay persons and ethics. J Agric Environ Ethics 20:37-52. doi:10.1007/s10806-006-9016-7

Tschiedel R (1989) Sozialverträgliche Technikgestaltung-Wissenschaftskritik für eine soziologische Sozialverträglichkeitsforschung zwischen Akzeptabilität. Westdeutscher Verlag, Opladen, Akzeptanz und Partizipation

UBA (Umweltbundesamt) (2006) Pilothafte Ermittlung und Analyse von Zielgruppen für die Information und Anhörung der Öffentlichkeit nach Art. 14 EG Wasserrahmenrichtlinie in einer Flussgebietseinheit. https://www.umweltbundesamt.de/sites/default/files/medien/ publikation/long/3116.pdf. Accessed 16 Dec 2015

UBA (Umweltbundesamt) (2012) Die Wasserrahmenrichtlinie-Eine Zwischenbilanz zur Umsetzung der Maßnahmenprogramme 2012. https://www.umweltbundesamt.de/sites/default/files/med ien/378/publikationen/wasserrahmenrichtlinie_2012.pdf. Accessed 16 Dec

Uhlendahl T (2009) Public participation in river basin management on the local level within the context of the WFD. University of Freiburg

van der Heijden J, ten Heuvelhof E (2012) The mechanics of virtue: lessons on public participation from implementing the water framework directive in the Netherlands. Environ Policy Govern 22:177-188. doi:10.1002/eet.1583

VDI 7001 (2014). Kommunikation und Öffentlichkeitsbeteiligung bei Planung und Bau von Infrastrukturprojekten. Düsseldorf

Völker J (2014) Analyse und Bewertung der Instrumente zur Umsetzung der Wasserrahmenrichtlinie sowie Verknüpfung zu den institutionellen Rahmenbedingungen-Wasserfachliche Aspekte; Endbericht für ein Forschungsvorhaben im Auftrag des SRU. Sachverständigenrat für Umweltfragen, Berlin. https:// www.umweltbundesamt.de/sites/default/files/medien/378/publi kationen/texte_25_2014_komplett_0.pdf. Accessed 18 Dec

Warner J, Winnubst M, Roth D (2011) Space for the river, space for citizens? Planning the Ooij and Overdiep polders, the Netherlands. In: de Groot WT, Warner J (eds) The social side of river management. Environmental science, engineering and technology. Nova Science Publishers Inc, New York, pp 97-112

WIKUE (Wuppertal Institut für Klima, Umwelt, Energie GmbH) Eds. Scheck H, Vallentin D, Venjakob (2013) Emscher 3.0.-From grey to blue. http://epub.wupperinst.org/frontdoor/index/index/ docId/5070. Accessed 16 Dec 2015 